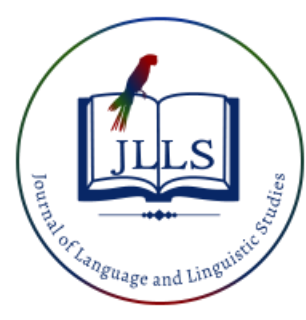

Available online at www.jlls.org

JOURNAL OF LANGUAGE AND LINGUISTIC STUDIES

ISSN: $1305-578 \mathrm{X}$

Journal of Language and Linguistic Studies, 16(4), 1869-1884; 2020

\title{
Use of gerunds and gerundial formations in written expressions of Arab learners of Turkish as a foreign language in $\mathrm{C} 1$ level
}

\author{
Salih Kürşad Dolunay a 1 iD , Hüseyin Karabuğa b iD \\ ${ }^{a}$ Bolu Abant İzet Baysal University, Bolu, Turkey \\ ${ }^{b}$ Bolu Abant Izzet Baysal University, Bolu, Turkey
}

\section{APA Citation:}

Dolunay, S. K. \& Karabuğa, H. (2020). Use of gerunds and gerundial formations in written expressions of Arab learners of Turkish as a foreign language in C1 level. Journal of Language and Linguistic Studies, 16(4), 1869-1884.

Submission Date:20/7/2020

Acceptance Date:22/10/2020

\begin{abstract}
Gerunds lead to great simplicity and functionality in the Turkish language while increasing the expressive power, enabling the expression to become more concise and fluent. In the Common European Framework of Reference for Languages (CEFR, henceforth), an accepted guide in teaching Turkish as a foreign language, the correct and effective use of gerunds and gerundial formations is accepted as one of the grammatical competencies required for learners in $\mathrm{C} 1$ level. However, a few studies in the literature have investigated the learners' success in $\mathrm{C} 1$ level regarding grammatical competence. Based on this literature gap, the purpose of the research is to examine the use of gerunds and gerundial formations in the written expressions of the Arab learners of Turkish as a foreign language at the $\mathrm{C} 1$ level. For this purpose, the research is designed as a qualitative case study. The study sample includes 150 Arab learners in the $\mathrm{C} 1$ level who studied at TÖMER in the Black Sea Region, Central Anatolia Region, and Marmara Region in the 2019-2020 academic year and voluntarily participated in the research. The research data were collected from the learners' written expressions in the final exam and analyzed using document analysis. The scope of the study only included gerunds and gerundial formations. Frequency analysis, one of the sub-techniques of content analysis, was used to analyze the data. The data revealed that the 150 learners used 32 different gerunds and gerund particles in their written expressions.
\end{abstract}

(C) 2020 JLLS and the Authors - Published by JLLS.

Keywords: gerund; gerundial formation; teaching Turkish as a foreign language; grammar teaching; Arab learners

\section{Introduction}

Language units with certain values and meanings when in relationship with each other construct language systems (Adal1, 2004). The values and meanings that language units have been marked, especially in the formation of words and sentences. As Turkish has an agglutinative structure, suffixes have a very significant role in the operation of the language, both in word construction and putting the words into use (Korkmaz, 2009, pp. 15-16). Suffixes cannot stand alone or have meaning by themselves and only have meaning when added to the root or stem (Ergin, 2004). They are essential as they attach

\footnotetext{
${ }^{1}$ Corresponding author.

E-mail address: dolunay_k@ibu.edu.tr
} 
to the root to make an affixed word, make the root and stem operational, and establish temporary meaning relations between the words in the sentence (Çotuksöken, 2011; Ergin, 2004; Korkmaz, 2007). Therefore, it should be highlighted that suffixes play an essential role in understanding the meanings of sentences. Besides, Korkmaz (2009) stated that in order to have a good understanding of the structure of the Turkish language (in Turkey), it is necessary to know the structural and functional characteristics of the system of suffixes (p. 16). It is especially crucial for those who learn Turkish as a foreign language to understand Turkish's structure to use the language accurately and fluently (Avc1, Tepeli, \& Caner, 2017). Thus, the teaching of suffixes with different forms and meanings is important in teaching Turkish as a foreign language. For it is required to establish a link between grammatical structure and meaning in language as a communication system, learners of Turkish should know how this link is established (Avc1 et al., 2017, p. 20).

\subsection{Literature review}

Studies on the use of gerunds and gerundial formations by international learners illustrate that learners have difficulties in understanding these structures (Alshirah, 2013; Güven, 2019; Hasırc1, 2018; Kasapoğlu, 2012; Kıvırcık, 2004; Koşucu, 2007; Polat, 2018). In the literature, the studies of gerund and gerundial formations can be divided into two groups; the first group of studies concern with the use of gerunds and gerundial formations focusing on error analysis (Albayrak, 2010; Bakır, 2015; Boylu, Güney \& Özyalçın, 2017; Büyükikiz \& Hasırc1, 2013; Esawi, 2015; İnan, 2013, 2014; Jarbold, 2012; Polat, 2014; Turhan, 2005; Yağmur Şahin, 2013) and the problems in language teaching and learning regarding these structures (Alshirah, 2013; Emiroğlu, 2013; Kara, 2010). These studies generally address the grammatical errors encountered in written expressions, treating the incorrect use of gerunds and gerundial formations cursorily. However, the works of Jarbold (2012), Polat (2014) and Turhan (2005) deserve close attention. Although Jarbold (2012) and Polat (2014) have not taken gerunds and gerundial formations as the focus of their studies, they have reported quantitative results about the incorrect uses. Similarly, Turhan (2005), in his study comparing Chinese and Turkish in terms of syntactic, also included syntax errors in the written expression papers of Chinese students studying in the department of Turcology in 3rd and 4th grade. The researcher included errors in sentence structures in which gerunds and gerundial formations were used while conveying the syntax errors of Chinese students. Turhan (2005) determined that students misused gerunds and gerundial formations 19 times in total. The rate of these errors in syntactic errors is $10.73 \%$. However, Turhan (2005) did not share any data regarding the error frequency related to the gerund types in this section. In addition, Turhan (2005) concluded that Chinese students often make mistakes when using gerund suffixes due to the absence of gerund suffixes in Chinese that are used to form compound sentences.

Another type of research is engaged directly with the use of gerunds and gerundial formations. These studies differ from the studies mentioned above for their detailed examination of gerunds and gerundial formations, enabling some inferences about the topic through empirical data. There are one doctoral dissertation and five master theses, and four articles in the literature that qualify for this type of research. Güven (2019) investigated the semantic analysis of the adverbial clauses in Turkish was conducted and the sème of these semantic units in Turkish in her doctoral thesis in the field of teaching Turkish as a foreign language. The researcher examined the Turkish teaching sets in terms of the use and teaching of gerunds and gerundial formations and tried to determine what method was followed in teaching. The researcher determined that in the field of teaching Turkish as a foreign language, gerunds and gerundial formations are taught with traditional methods, just like in the mother tongue. In addition, it was determined that semantics are not taken into account in the teaching of gerunds. Likewise, three of the master theses (Deniz, 2017; K1lıç, 2017; Koşucu, 2007) focus on the usage frequency of gerunds in Turkish teaching sets while one suggests the problems and suggests solutions in the teaching of gerunds 
(Kıvircik, 2004). The other thesis investigates material development for teaching gerundial suffixes (Kasapoğlu, 2012). Among the mentioned studies, Kasapoğlu (2012) and Koşucu (2007) are the ones that are directly related to gerunds and gerundial formations. Kasapoğlu (2012), prepared course materials for the "-(y)ArAk", "-(y)Ip", "-(y)IncA" and "-(y)AlI" gerunds for B2 level students. For this, the researcher first examined the Turkish teaching sets "Yeni Hitit Yabancılar İçin Türkçe", "Orhun Yabancılar İçin Türkçe" and "Gökkuşağı". After examining how gerunds are taught in Turkish teaching sets, the researcher used a task-oriented method for gerund attachments and prepared different materials. The researcher also shared the materials with five students who learned Turkish at intermediate and advanced levels and took their opinions. However, the inferences obtained from the students' ideas are not included in the conclusion section. Koşucu (2007), in her thesis, gerunds and gerundial formations have been scrutinized within the context of teaching Turkish to foreigners, based on the books Hitit 1-2-3 to find out whether they are suitable or not according to projected language levels. The suitability of reading and comprehension texts used in teaching gerunds and the exercises that have been implemented in each course level was investigated. Teaching gerunds and gerundial formations; considering the frequency and ease of use and the suitability for the level, the Hitit set was found successful. It was also determined that the Hitit set gave more wide publicity to gerunds and gerundial formations than other sets.

In addition, one of the four research articles, which directly investigates gerunds, is carried out by İlker (2019). In this study, İlker (2019) finds out that the learners of the Faculty of Philology, Department of Kazakh Linguistics at L. N. Gumilev University misuse the suffixes "-p", "-(y)ArAk", and "-A". The second study in the literature is by Polat (2018). Polat (2018) investigates the equivalents and positions of "-(y)Ip", "-mAyIp" and "-mAdAn" in Russian, Arabic, and English. The third study is by Hasırc1 (2018). Hasırci's (2018) study reports the views of educators working in teaching Turkish as a foreign language about teaching gerunds and gerundial formations and includes the gerunds, gerundial formations, and their usage patterns in Turkish teaching sets. And the fourth study is by Şen, Köleci \& Tülü (2015). Şen, Köleci \& Tülü (2015) focused on the "-(y)ArAk", "-(y)Ip", “-DIktan sonra” gerunds and gerundial formations in their study with 100 students at A2.2 and B1.1 levels. Şen, Köleci \& Tülü (2015) taught students the meaning relationships and functions of these gerunds and gerundial formations using explicit and implicit teaching methods. After the training they gave, the researchers examined the errors in the students' written expression sheets. The data obtained showed that the training is given for gerunds and gerundial formations were unsuccessful. However, researchers; concluded that the focus should be on the functions of gerunds and gerundial formations, the way they are presented, and the order in which they are presented.

\subsubsection{Gerunds and gerundial formations}

One of the Turkish suffixes that have essential functions in terms of use and meaning is gerundial suffixes. Gerunds are linguistic elements that enrich the expressive power making languages more fluent, make the intended message conveyed more concisely (Aksan, 1998; Bozkurt, 2017), allow the formation of subordinate clauses (Korkmaz, 2009), and function as a conjunction (Demir, 2004). Gerunds, which are formed from verbs by adding suffixes, play an essential role in understanding the meaning of sentences (Avc1 et al., 2017, p. 20). Gerunds, which can be added to positive and negative verbs in Turkish, are categorized into three: verbal noun, verbal adjective (the gerundive), and verbaladverb (gerund).

The present study is interested in the last category of gerunds. In Turkish, various terms were coined for this category of gerunds, such as zarf-fiil (verbal adverbs), gerundif (the gerundive), şahıssiz kip (impersonalized modal), ulaç (the gerundive), bağ fiil (gerund), ulaç-fiil (gerund), and gerundium (Bayraktar, 2018, p. 137). In this study, the terms "gerunds and gerundial formations" have been selected since they are more inclusive and up to date. 
Korkmaz (2009, p. 983) proposes that gerunds maintain both verb-like and adverb-like properties, and the former covers the motion and temporal aspects while the latter is qualified to determine the status and style of formation and action. In other words, verbal adverbs function as an aid to fulfill the adverbial tasks. Atabay, Kutluk, and Özel (1983, p. 273) define gerunds as words in contemporary Turkish derived from verbs yet mostly function as adverbs in the sentence. Deniz Y1lmaz (2009) states,

"Gerunds are a form of verbs which are finite or nonfinite and inflectional or noninflectional, and they indicate the action in the verb stem and represent one of the meanings in the mobile adverbial form such as style of action, comparison, time, cause and effect, contradiction/inconsistency, displacement, replacement, condition, and purpose (p. 93)."

Based on the literature, gerunds can be defined as follows: Gerunds are impersonalized and aspectfree structures derived from verbs (Ergin, 2004; Hengirmen, 1995). They are used with auxiliary verbs to form compound verbs and compound sentences (Bayraktar, 2018; Korkmaz, 2009). They function as adverbs (Atabay et al., 1983; Gülsevin, 2001; Koç, 1996) and modify and complement the verbs of the main or subordinate sentences (Karahan, 1995). They act as a verb when they form a clause and as a conjunction when they attach the subordinate clause they form to the main clause (Demir, 2004). They consist of a special form of verbs to function as verbal adverbs (Banguoğlu, 2007), and they are inflectional and finite/non-finite structures (Guzev \& Y1lmaz, 2015). These definitions also apply to gerundial formations. Gerundial formations are structures in which some suffixes and particles (postpositions in Turkish) are used together, acting and functioning as gerunds in the sentence.

While defining gerunds and gerundial formations, some properties and tasks they are assigned should be addressed. Introducing the properties and assigned tasks of gerunds and gerundial formations is essential to make the semantic differences clear (Çetintaş Yıldırım, 2010). Table 1 demonstrates the properties and some assigned tasks of gerunds and gerundial formations.

Table 1. The properties and some assigned tasks of gerunds and gerundial formations

\begin{tabular}{|c|c|}
\hline Reference & The properties and assigned tasks \\
\hline $\begin{array}{l}\text { Bayraktar, 2018; Bozkurt, } \\
2017\end{array}$ & $\begin{array}{l}\text { Gerunds and gerundial formations are not conjugated and do not take } \\
\text { possessive or case suffixes. }\end{array}$ \\
\hline $\begin{array}{l}\text { Atabay et al., 1983; } \\
\text { Bayraktar, 2018; Gülsevin, } \\
\text { 2001; Koç, } 1996\end{array}$ & Gerunds and gerundial formations function as adverbs in the sentence. \\
\hline Korkmaz, 2009 & $\begin{array}{l}\text { Gerunds and gerundial formations are used with auxiliary verbs to form } \\
\text { compound verbs and compound sentences. }\end{array}$ \\
\hline $\begin{array}{l}\text { Demir, 2004; Koç, 1996; } \\
\text { Ünal, } 2010\end{array}$ & $\begin{array}{l}\text { Gerunds and gerundial formations form subordinate clauses and attach them } \\
\text { to the main clauses and help form simple sentences. }\end{array}$ \\
\hline $\begin{array}{l}\text { Bayraktar, 2018; Benhür, } \\
\text { 1993; Bozkurt, 2017; } \\
\text { Çetintaş Y1ldırım, 2010; } \\
\text { Dolunay, 2012; } \\
\text { Hepçilingirler, } 2018\end{array}$ & $\begin{array}{l}\text { Some functions of gerunds and gerundial formations include linking } \\
\text { statements in a sentence and indicating the properties of time and manner } \\
\text { (beginning, marking, preceding, following, ending, timing), causation, } \\
\text { comparison, contradiction, and continuation. }\end{array}$ \\
\hline
\end{tabular}

With the properties and assigned tasks, gerunds and gerundial formations bring simplicity and functionality to the Turkish language (Kasapoğlu, 2012). The reason is that subordinate clauses attach to main clauses through verbal adjectives and verbal adverbs and make the expression concise and fluent 
(Aksan, 1998). In other words, gerunds increase Turkish's expressive power and allow us to shorten the expressions to a single statement, thus preventing redundancy (Koç, 1996).

On the other hand, Kasapoğlu (2012), stating that there are many gerundial suffixes in Turkish, asserts that no firm consensus about gerundial suffixes has been reached in the literature (p. 47). Relying on the categorization by Ergin, Banguoğlu, Gencan, Ediskun, Bilgegil, and Korkmaz, Gülsevin (2001, p. 126) reviews the literature and determines that "-(y)A", “-(y)All”, “-(y)ArAk", “-(y)IncA", “-(y)Ip", "-ken", and "-mAdAn" are the gerundial suffixes that have commonly appeared in the literature, alongside examining many other gerunds and gerundial formations.

Table 2 displays various classifications of gerunds and gerundial formations in the literature.

Table 2. Classification of gerunds and gerundial formations in the academic literature

\begin{tabular}{|c|c|}
\hline Reference & $\begin{array}{l}\text { Categorization models and the gerunds and gerundial formations included in } \\
\text { the categories }\end{array}$ \\
\hline $\begin{array}{l}\text { Ediskun }(1999, \mathrm{pp} . \\
\text { 252-272) }\end{array}$ & $\begin{array}{l}\text { 1) bağlama ulaçları (gerunds of conjunction), 2) durum ulaçları (gerunds of } \\
\text { manner), 3) zaman ulaçları (gerunds of time), 4) neden ulaçları (gerund of } \\
\text { causation), 5) kıyaslama ulaçları (gerunds of comparison), 6) bedel ulaçları } \\
\text { (gerunds of cost) }\end{array}$ \\
\hline $\begin{array}{l}\text { Gencan (2001, pp. } \\
\text { 256-267) }\end{array}$ & $\begin{array}{l}\text { 1) verbal adverbs with the suffix -(y)Ip, bağlama zarf-fiilleri (verbal adverbs of } \\
\text { conjunction), 2) durum zarf-fiilleri (verbal adverbs of manner), 3) artç1l zarf- } \\
\text { fiiller (verbal adverbs of posteriori), 4) başlama zarf-fiilleri (verbal adverbs } \\
\text { signaling beginning), 5) bitirme zarf-fiilleri (verbal adverbs signaling ending), } \\
\text { 6) zaman zarf-fiilleri (verbal adverbs of time), 7) nedenlik zarf-fiili (verbal } \\
\text { adverbs of causation), 8) verbal adverbs with the suffix -dı mi, 9) verbal adverbs } \\
\text { with diye, 10) verbal adverbs with -an, -ana, and 11) verbal adverbs derived } \\
\text { from verbal nouns }\end{array}$ \\
\hline
\end{tabular}

Banguoğlu (2007, pp. 1) ulama zarf-fiilleri (verbal adverbs of conjunction), 2) hâl zarf-fiilleri (verbal 428-440) adverbs of cases), 3) karşıtlama zarf-fiilleri (verbal adverbs of contradiction), 4) zaman zarf-fiilleri (verbal adverbs of time), 5) sebep zarf-fiilleri (verbal adverbs of causation), and 6) karşılaştırma zarf-fiilleri (verbal adverbs of comparison)

Korkmaz (2009, pp. 1) formal aspects: gerçek zarf-fiiller (real verbal adverbs), ad-fiil ve sifat980-1046) fiillerle kurulan zarf-fiiller (verbal adverbs formed with verbal nouns and verbal adjectives), değişik yapıdaki zarf-fiiller (verbal adverbs with different structures)

2) functional aspects: tarz ve zaman bildiren zarf-fiiller (verbal adverbs of style and time)

Bayraktar (2018,pp. 1) sifat-fiilden türeyen zarf-fiiller (verbal adverbs derived from verbal 138-264) adjectives)

2) isim-fiillerden türeyen zarf-filler (verbal adverbs derived from verbal nouns)

Despite the existing categorization practices in the literature, some scholars favor working on gerunds and gerundial formations without categories (Bozkurt, 2017; Ergin, 2004; Hepçilingirler, 2018; Karaağaç, 2016; Koç, 1996; Ünal, 2010). These classifications cause some confusion in teaching gerunds both in the native language and Turkish as a foreign language (Hasirc1, 2018). Thus, a consensus 
about gerunds, gerundial formations, and their classification is needed for the Turkish language teaching practices and the development of course content and materials.

\subsubsection{Gerunds and gerundial formations in teaching Turkish as a foreign language}

The CEFR is accepted as a guide in teaching Turkish as a foreign language. The text addresses grammar acquisition under 'grammatical competence' and 'writing skill' (CEFR, 2018; CEFR, 2013). Although only indirectly stated, according to the CEFR, correct and effective use of gerunds is one of the skills that language users are expected to acquire. In CEFR (2013, p. 151), the sentence is considered part of the grammatical competence with other connections far beyond its boundaries (i.e., anaphora: the use of pronoun and gerundial of adverbs that strengthen the sentence). As can be inferred, gerunds' use to form sentences with various connections is a part of grammatical competence.

In the updated version of the CEFR (2018), it is notable that grammatical competencies, which can be considered to cover the use of gerunds in $\mathrm{C} 1$ level, are approached in a more detailed and tangible manner thanks to various assessments tools. Table 3 presents the descriptors of competencies, including hints about the use of gerunds (CEFR, 2018).

Table 3. C1 level grammatical competence

\begin{tabular}{|c|c|c|}
\hline Main category & $\begin{array}{l}\text { Sub- } \\
\text { category }\end{array}$ & Descriptors \\
\hline \multirow[t]{3}{*}{ Written Expression Assessment } & Accuracy & $\begin{array}{l}\text { Consistently maintains a high degree of grammatical } \\
\text { accuracy; occasional errors in grammar, collocations and } \\
\text { idioms (CEFR, 2018, p. 173). }\end{array}$ \\
\hline & $\begin{array}{l}\text { General } \\
\text { Linguistic } \\
\text { Range }\end{array}$ & $\begin{array}{l}\text { Can use a broad range of complex grammatical structures } \\
\text { appropriately and with considerable flexibility. Can select } \\
\text { an appropriate formulation from a broad range of } \\
\text { language to express him/herself clearly, without having to } \\
\text { restrict what he/she wants to say (CEFR, 2018, p. 131). }\end{array}$ \\
\hline & $\begin{array}{l}\text { Grammatical } \\
\text { Accuracy }\end{array}$ & $\begin{array}{l}\text { Consistently maintains a high degree of grammatical } \\
\text { accuracy; errors are rare and difficult to spot (CEFR, } \\
2018 \text {, p. 133). }\end{array}$ \\
\hline Grammatical Accuracy & Flexibility & $\begin{array}{l}\text { Can make a positive impact on an intended audience by } \\
\text { effectively varying style of expression and sentence } \\
\text { length, use of advanced vocabulary and word order } \\
\text { (CEFR, 2018, p. 139). }\end{array}$ \\
\hline
\end{tabular}

Considering the explanations in Table 3, it appears that the learners learning Turkish as a foreign language are expected to use gerunds and gerundial formations consistently, correctly, and effectively. C1 level learners are expected to use an advanced vocabulary for particular concepts and change the style of expression and sentence length playing with the word order in order to make a positive impact on an intended audience (CEFR, 2018, p. 139). Gerunds and gerundial formations in Turkish allow a change in word order, the style of expression, and sentence length (Aksan, 1998; Bayraktar, 2018; Demir, 2004; Koç, 1996; Korkmaz, 2009; Ünal, 2010). Thus, gerunds and gerundial formations should be covered in teaching Turkish as a foreign language. On the other hand, it is also important to teach the form, use, and meaning (Larsen-Freeman, 2001) of gerunds and gerundial formations. Grammatical structures are not limited to their formal properties, and they are also used to convey meaning in different contexts (Hasirc1, 2018, p. 184). When those who learn Turkish as a foreign language comprehend the 
Turkish language's richness and functionality, they discover the different semantic features with grammatical structures and use them effectively in oral and written products.

\subsection{Research question}

Based on the above explanations, the present study investigates the following research question: What is the case with the use of gerunds and gerundial formations in the written expressions of the Arab learners of Turkish as a foreign language at the $\mathrm{C} 1$ level?

It has been apparent that the studies concerning the use of gerunds and gerundial formations by Arab learners of Turkish as a foreign language are scarce. Nevertheless, most immigrants' native language coming to Turkey in recent years is Arabic (TÜIK, 2019), and these people show great interest in Turkish. Therefore, there is a need for more elaborate studies on gerunds and gerundial formations used by Arab learners of Turkish as a foreign language. This need also marks the significance of the current study.

\section{Method}

\subsection{Research design}

The current study was designed as a qualitative case study. A case study is (1) a research approach that engages in a current case within its real-life framework (content), (2) the boundaries between the case and the content are not clearly defined, and (3) the approach is employed when there are multiple sources of evidence or data available (Yıldırım \& Şimşek, 2016, p. 289). A qualitative case study design was selected to determine the case with the use of gerunds and gerundial formations in the written expressions of the Arab learners of Turkish as a foreign language at the $\mathrm{C} 1$ level.

\subsection{Participants}

The study sample consists of 150 Arab learners in C1 level who studied at TÖMER in the Black Sea Region, Central Anatolia Region, and Marmara Region in the 2019-2020 academic year and voluntarily participated in the research.

Table 4. The Qualities of the Participants

\begin{tabular}{|c|c|c|c|c|c|c|}
\hline & & $\begin{array}{l}\text { A. TÖMER in the } \\
\text { Black Sea Region }\end{array}$ & $\begin{array}{c}\text { B. TÖMER in the } \\
\text { Central Anatolia Region }\end{array}$ & $\begin{array}{l}\text { C. TÖMER in the } \\
\text { Marmara Region }\end{array}$ & Total & $\begin{array}{l}\text { Grand } \\
\text { Total }\end{array}$ \\
\hline \multirow[t]{2}{*}{ Gender } & Male & 30 & 40 & 25 & 95 & 150 \\
\hline & Female & 20 & 10 & 25 & 55 & \\
\hline \multirow[t]{3}{*}{ Age } & $18-27$ & 35 & 40 & 45 & 120 & \\
\hline & $28-37$ & 12 & 5 & 3 & 20 & 150 \\
\hline & $38+$ & 3 & 5 & 2 & 10 & \\
\hline \multirow[t]{4}{*}{ Country } & Iraq & 25 & 15 & 20 & 60 & \\
\hline & Syria & 10 & 20 & 5 & 35 & 150 \\
\hline & Palestine & 10 & 5 & 15 & 30 & \\
\hline & Jordan & 5 & 10 & 10 & 25 & \\
\hline
\end{tabular}




\subsection{Data collection and analysis}

The data were collected from the learners' written expressions in the final exam and analyzed using document analysis as a method. Collecting data by examining the existing records and documents is called document analysis (Karasar, 2012, p.183). The data were limited to gerunds and gerundial formations, and verbal nouns and verbal adjectives were excluded. The first step in the research was to determine the sentences with gerunds and gerundial formations, analyzing the learners' written expressions. Initially, the correct and incorrect uses of gerunds and gerundial formations in the sentences were classified.

Frequency analysis, one of the sub-techniques of content analysis, was used to analyze the data. Content analysis allows us to identify certain words or concepts in a set of text or texts (Büyüköztürk, Çakmak, Akgün, Karadeniz, \& Demirel, 2016, p. 250). Frequency analysis, in its simplest form, reveals the frequency of units or items appearing in a numerical, percental, and proportional manner (Bilgin, 2014, p. 18). Thus, the researchers can identify the existence, frequency, meaning, and relationships of certain units and explain their importance and effects (Bilgin, 2014; Büyüköztürk et al., 2016). The data collected for the study were analyzed based on the category of gerunds and gerundial formations. The findings demonstrated the learners' correct and incorrect uses of gerunds and gerundial formations. No limitations have been applied to the selection of gerundial suffixes and gerundial formations, and all of the identified ones in the learners' written expressions were recorded. The researchers consulted two field experts during the data analysis. Also, the researchers benefited from a data analysis they developed during the data analysis process. Table 5 displayed the form used for data analysis.

Table 5. Data analysis form

\begin{tabular}{|c|c|c|c|c|}
\hline 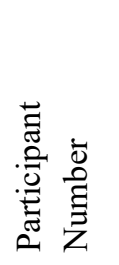 & 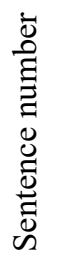 & $\begin{array}{c}\text { Sentence } \\
\text { Data }\end{array}$ & $\begin{array}{l}\text { Correct uses of } \\
\text { gerund/gerundial } \\
\text { formations }\end{array}$ & $\begin{array}{l}\text { Incorrect uses of } \\
\text { gerund/gerundial } \\
\text { formations }\end{array}$ \\
\hline $\mathrm{A} 1$ & 1 & & & \\
\hline A2 & 2 & & & \\
\hline $\mathrm{A} 3$ & 3 & & & \\
\hline
\end{tabular}

\section{Results}

The results of the study were presented below.

Results of the study: The results below uncovered the case with the use of gerunds and gerundial formations in the written expressions of the Arab learners of Turkish as a foreign language at the $\mathrm{C} 1$ level. 
Table 6. The case of C1 level Arab learners' use of gerunds and gerundial formations

\begin{tabular}{|c|c|c|c|c|c|c|}
\hline No & $\begin{array}{l}\text { Gerund and gerundial } \\
\text { formations }\end{array}$ & $\begin{array}{l}\text { Correct uses } \\
\text { (f) }\end{array}$ & $\begin{array}{c}\text { Correct } \\
\text { uses }(\%)\end{array}$ & $\begin{array}{l}\text { Incorrect } \\
\text { uses (f) }\end{array}$ & $\begin{array}{l}\text { Incorrect } \\
\text { uses }(\%)\end{array}$ & Total uses \\
\hline 1 & -mAk için & 184 & 93,88 & 12 & 6,12 & 196 \\
\hline 2 & -(y)ArAk & 89 & 90,82 & 9 & 9,18 & 98 \\
\hline 3 & -ken & 61 & 92,43 & 5 & 7,57 & 66 \\
\hline 4 & $-(y) I p$ & 44 & 95,66 & 2 & 4,34 & 46 \\
\hline 5 & $\begin{array}{l}\text {-DIğImda/ -DIğIndA/ } \\
\text {-DIğImIzdA/ -DIğInIzdA }\end{array}$ & 24 & 88,89 & 3 & 11,11 & 27 \\
\hline 6 & -DIğI/-DIğImIz/ -DIklArI için & 21 & 84 & 4 & 16,0 & 25 \\
\hline 7 & $\begin{array}{l}\text {-DIğI/ -DIğIm/ -DIğImIz/ } \\
\text {-DIğInIz/ -DIklArI zaman }\end{array}$ & 17 & 70,84 & 7 & 29,16 & 24 \\
\hline 8 & -DIktAn sonra & 19 & 82,61 & 4 & 17,39 & 23 \\
\hline 9 & $-(y) \operatorname{IncA}$ & 15 & 68,19 & 7 & 31,81 & 22 \\
\hline 10 & -mAsI için & 12 & 70,59 & 5 & 29,41 & 17 \\
\hline 11 & - mAdAn & 10 & 83,34 & 2 & 16,66 & 12 \\
\hline 12 & $\begin{array}{l}\text {-DIğI/-DI ğIm/ -DIğImIz/ } \\
\text {-DIklArI gibi }\end{array}$ & 9 & 81,82 & 2 & 18,18 & 11 \\
\hline 13 & -DIkçA & 9 & 100 & 0 & 0 & 9 \\
\hline 14 & -mAsInA rağmen & 7 & 77,78 & 2 & 22,22 & 9 \\
\hline 15 & -mAdAn önce & 6 & 75,0 & 2 & 25,0 & 8 \\
\hline 16 & $-\mathrm{Ar} \ldots-\mathrm{mAz}$ & 3 & 100 & 0 & 0 & 3 \\
\hline 17 & -mAktAn & 1 & 33,34 & 2 & 66,66 & 3 \\
\hline 18 & -A kadar & 0 & 0 & 2 & 100 & 2 \\
\hline 19 & -DIğI hâlde & 2 & 100 & 0 & 0 & 2 \\
\hline 20 & -DIğImIz sürece & 2 & 100 & 0 & 0 & 2 \\
\hline 21 & -(y)IncAyA kadar & 1 & 50,0 & 1 & 50,0 & 2 \\
\hline 22 & -mAksIzIn & 2 & 100 & 0 & 0 & 2 \\
\hline 23 & -mAmIz için & 2 & 100 & 0 & 0 & 2 \\
\hline 24 & ...A ...A & 1 & 100 & 0 & 0 & 1 \\
\hline 25 & -DIğI kadar & 0 & 0 & 1 & 100 & 1 \\
\hline 26 & -DIğI ölçüde & 1 & 100 & 0 & 0 & 1 \\
\hline 27 & -DIğIm müddetçe & 1 & 100 & 0 & 0 & 1 \\
\hline 28 & -DIğIndAn & 1 & 100 & 0 & 0 & 1 \\
\hline 29 & -DIğIndAn beri & 1 & 100 & 0 & 0 & 1 \\
\hline 30 & -DIğInI rağmen & 0 & 0 & 1 & 100 & 1 \\
\hline 31 & -mAktAn dolayı & 1 & 100 & 0 & 0 & 1 \\
\hline 32 & -mAktAnsA & 1 & 100 & 0 & 0 & 1 \\
\hline
\end{tabular}

Table 6 illustrated the Arab learners' use of gerunds and gerundial formations in their written expressions at the $\mathrm{C} 1$ level. Table 6 , which was conducted to identify the use of gerunds and gerundial formations in the written expressions of the Arab learners of Turkish as a foreign language at the $\mathrm{C} 1$ level, revealed that the 150 learners used 32 different gerunds and gerund particles in their written expressions. The data collected from the use of gerunds and gerundial formations projected how Turkish was a language allowing a wide and varied range of expressions. Hence, Koşucu (2007) also asserted that Turkish had a wealth of gerunds and gerundial formations compared to other languages and that there were around 60 gerunds in Turkish.

The most frequently used gerunds and gerundial formations by the Arab learners were "-mAk için" (f=196), “-(y)ArAk" (f=98), “-ken” (f=66), “-(y)Ip” (f=46), “-DIğImda/ -DIğIndA/ -DIğImIzdA/ -DIğInIzdA” (f=27),” -DIğI/DIğImIz/DIklArI için” (f=25), “-DIğg/ -DIğIm/ -DIğImIz/ -DIğInIz/ -DIklArI zaman" (f=24), “-DIktAn sonra” (f=23), “-(y)IncA” (f=22) and "-mAsI için" (f=17). 
The gerunds and gerundial formations that the Arab learners used with the fewest number of errors were "-DIkçA" (f=9, \%100), "-Ar ...mAz" (f=3, \%100), "-DIğI hâlde" (f=2, \%100), "-mAksIzIn" (f=2, \%100), "-mAmIz için" (f=2, \%100), “...-A ...-A” (f=1, \%100), “-DIğI ölçüde” (f=1, \%100), "-DIğIm müddetçe" (f=1, \%100), "-DIğIndAn" (f=1, \%100), "-DIğIndAn beri” ( $\mathrm{f}=1, \% 100)$, "-mAktAn dolayı" ( $\mathrm{f}=1, \% 100)$, and "-mAktAnsA" ( $\mathrm{f}=1, \% 100)$ respectively. On the other hand, the gerunds and gerundial formations that the Arab learners used in their written expressions with the highest number of errors were "-A kadar" ( $\mathrm{f}=2, \% 100)$, “-DIğI kadar" ( $\mathrm{f}=1, \% 100)$, “-DIğInI rağmen" (f=1, \%100), “-mAktAn" $(\mathrm{f}=3, \% 66,66)$, and "-IncAyA kadar" ( $\mathrm{f}=2, \% 50)$ " respectively.

\section{Discussion}

The study revealed that the most frequently used gerunds and gerundial formations by the Arab learners were "-mAk için” (f=196), “-(y)ArAk” ( $\mathrm{f}=98)$, “-ken” ( $\mathrm{f}=66)$, “-(y)Ip” (f=46), “-DIğImda/ -DIğIndA/-DIğImIzdA/ -DIğInIzdA" (f=27), "-DIğg/-DIğImIz/ -DIklArI için" (f=25), “-DIğI/ -DIğIm/ -DIğImIz/-DIğInIz/ -DIklArI zaman” (f=24), “-DIktAn sonra” (f=23), "-(y)IncA” (f=22) and "-mAsI için" ( $\mathrm{f}=17)$. The learners' frequent use of gerunds and gerundial formations in their written expressions can be explained by the fact that they have studied these structures in the lessons and Turkish teaching sets and reached the level of competence to use them communicatively. Data supporting this interpretation was shared by Güven (2019). Güven (2019, p. 287) stated that in the set of "Yeni Hitit Yabancilar İçin Türkçe", the most frequently used gerunds and gerundial formations; "-(y)ArAk" (291 times), "-(y)Ip" (210 times), "-mAk için" (148 times), "-ken" (115 times), "-DIğIndA" (58 times), "-(y)IncA" (48 times), "-mAdAn" (44 times) and "-DIğI için" (42 times) found that. In addition, studies suggesting that Turkish teaching sets are adequate in terms of use and variety of gerunds and gerundial formations (Deniz, 2017; Güven, 2019; Kılıç, 2017; Koşucu, 2007) also supported this explanation. However, it appeared that this explanation did not apply to all gerunds. The most frequently used gerunds and gerundial formations with the highest number of errors in the Arab learners' written expressions in $\mathrm{C} 1$ level needed a careful examination.

The study showed that "-A kadar" (f=2, \%100), "-DIğI kadar" ( $\mathrm{f}=1, \% 100)$, "-DIğInI rağmen" ( $\mathrm{f}=1$, \%100), "-mAktAn" ( $\mathrm{f}=3, \% 66,66)$ and "-IncAyA kadar" ( $\mathrm{f}=2, \% 50)$ were the gerunds and gerundial formations with the highest number of errors committed by the Arab learners. However, it should be noted that these structures are lower in usage frequency compared to other structures. Therefore, the relationship between the number of uses and the ratio of incorrect uses must be taken into account. Accordingly, the most frequently used gerunds and gerundial formations with the highest number of errors were “-(y)IncA” (f=22, \%31,81), “-mAsI için” (f=17, \%29,41), “-DIğI/-DIğIm/-DIğImIz/ -DIğInIz/-DIklArI zaman" ( $\mathrm{f}=24, \% 29,16)$ and "-mAdAn önce" $(\mathrm{f}=8, \% 25)$ respectively. The frequent misuse of these structures may have resulted from the linguistic differences between Turkish and Arabic. The reason is that the sentence structure of the Turkish language, the form of connection with clauses, the structure of noun phrases, and item equivalence is different from Arabic (Alshirah, 2013; Polat, 2018; Sezer, 1991; Uçar, 2019). The Arabic language also has masculine-feminine and singular-plural agreement in verbal adjectives and verbal adverbs (gerunds) (Sezer, 1991, p. 29). Besides, linguistic differences with languages such as the use of five types of maf'ul (words functioning as an object, indirect object and adverbial clause) in Arabic, tamyiz (constructions of adjectives of quantity describing measurement, amount, or number + nouns), and postpositions may prevent Arab learners from using gerunds and gerundial formations correctly (Polat, 2018; Uçar, 2019). For instance, in Arabic, gerunds may not take suffixes and can simply be constructed with the present progressive form of the second verb (Polat, 2018, p. 103). It is not the case in Turkish. There is a need for comprehensive contrastive analytic studies to analyze these differences between Turkish and Arabic and determine their effects on 
the teaching of these languages. It is also important to draw attention to the suffix "-mAdAn önce" in particular. The reason was that "-mAdAn önce" is quite frequent in Turkish teaching sets and taught at the beginner level (A1 and A2 levels). The data also showed that although "-mAdAn önce" was taught at the beginner level, the Arab learners in $\mathrm{C} 1$ level frequently (25\%) misused it. At this point, we may review and critique Turkish teaching sets and the course content. The Turkish teaching sets do not recycle the gerunds in teaching, and the example sentences of gerunds do not correspond to the levels; thus, it prevents learners permanently from learning gerunds and gerundial formations (Koşucu, 2007). Furthermore, the sets give less attention to the teaching of gerunds and gerundial formations than verbal nouns and verbal adjectives (K1lıc, 2017). Therefore, it is important to teach gerunds and gerundial formations with the right materials, methods, and techniques in an inclusive manner. Kasapoğlu (2012) also suggested that materials that appealed to sense organs and could positively affect learners' construction of academic self were required to teach gerunds and gerundial formations. On the other hand, language teaching approaches, methods, and techniques that dominate teaching materials and the Turkish teaching sets should be examined. In the CEFR, an accepted guide in teaching Turkish as a foreign language, three-dimensional (form, use, and meaning) grammar teaching method (LarsenFreeman, 2001) was recommended to improve grammatical competence (CEFR, 2013, p. 151). Similarly, the use of instructional materials based on the communicative approach, task-based method and three-dimensional grammar teaching method (form, use, and meaning) are recommended to facilitate the learning of gerunds and gerundial formations (Hasırc1, 2018; Kasapoğlu, 2012; Kıvırcık, 2004). However, it is observed that these matters are not taken into consideration in most of the Turkish teaching sets (Hasırc1, 2018; Koşucu, 2007). The use of these innovative approaches and teaching methods and techniques in material development to teach gerunds can make significant differences.

The data of the study showed that the gerunds and gerundial formations that the Arab learners used in written expressions with the fewest number of errors were "-DIkçA" ( $\mathrm{f}=9, \% 100)$, "-Ar ...-mAz" (f=3, \%100), "-DIğI hâlde" ( $\mathrm{f}=2, \% 100)$, "-mAksIzIn" ( $\mathrm{f}=2, \% 100)$, “-mAmIz için" ( $\mathrm{f}=2, \% 100)$, “...-A ...-A" (f=1, \%100), "-DIğI ölçüde" (f=1, \%100), "-DIğIm müddetçe” (f=1, \%100), "-DIğIndAn" (f=1, \%100), “-DIğIndAn beri” ( $\mathrm{f}=1, \% 100)$, "-mAktAn dolayı" (f=1, \%100), and "-mAktAnsA" (f=1, $\% 100)$. There is, in fact, a notable matter that cannot be overlooked. These structures were generally restricted a limited number of uses. Therefore, the relationship between the number of uses and the ratio of correct uses should be taken into consideration. The gerunds and gerundial formations that the learners used the most commonly with the fewest number of error were "-DIkçA" ( $\mathrm{f}=9, \% 100)$, "-(y)Ip" (f=46, \%95,66), "-mAk için" ( $\mathrm{f}=196, \% 993,88)$, “-ken" ( $\mathrm{f}=66, \% 92,43)$, “-(y)ArAk” (f=98, \%90,82), "-DIğImda/-DIğIndA/ -DIğImIzdA/ -DIğInIzdA” (f=27, \%88,89), “-DIğI/ -DIğImIz/-DIklArI için” (f=25, \%84), "-mAdAn" (f=12, \%83,34), "-DIktAn sonra" (f=23, \%82,61) and "-DIğI/-DIğIm/ -DIğImIz/ -DIklArI gibi” ( $\mathrm{f}=11, \% 81,82)$ respectively. The gerundial suffixes "-(y)Ip" and "-mAdAn" needed a further explanation since our findings contradicted the existing literature. Polat (2018) has come to the conclusion that native speakers of Arabic may have difficulties in comprehending "-(y)Ip" and "-mAdAn" since Turkish and Arabic belonged to different language families, and the external structure and use of gerundial suffixes "-(y)Ip" and "-mAdAn" were different in both languages. However, the findings obtained from written expressions of the Arab learners contradicted Polat's (2018) assumption. Our findings demonstrated that the Arab learners in C1 level use "-(y)Ip" and "-mAdAn" correctly with a percentage of 95.66 and 83.34, respectively. The percentages illustrated that the Arab learners did not have difficulty in learning and understanding “-(y)Ip" and "-mAdAn". 


\section{Conclusions}

The study showed that the Arab learners used 32 different gerunds and gerundial formations in their written expressions. The learners' frequent use of "-mAk için" ( $\mathrm{f}=196)$, "-(y)ArAk" (f=98), "-ken" (f=66), “-(y)Ip” (f=46), “-DIğImda/ -DIğIndA/-DIğImIzdA/ -DIğInIzdA” (f=27), “-DIğI/-DIğImIz/ -DIklArI için" (f=25), "-DIğI/ -DIğIm/ -DIğImIz/-DIğInIz/ -DIklArI zaman" (f=24), "-DIktAn sonra" $(\mathrm{f}=23)$, "-(y)IncA" (f=22) and "-mAsI için" ( $\mathrm{f}=17)$ gerunds' and gerundial formations' in their written expressions is explained by the fact that they have studied these structures in the lessons and Turkish teaching sets and reached the level of competence to use them communicatively. The study showed that “-A kadar" (f=2, \%100), “-DIğI kadar" ( $\mathrm{f}=1, \% 100)$, “-DIğInI rağmen” ( $\mathrm{f}=1, \% 100)$, “-mAktAn" (f=3, $\% 66,66)$ and "-IncAyA kadar" ( $\mathrm{f}=2, \% 50)$ were the gerunds and gerundial formations with the highest number of errors committed by the Arab learners. But these structures are lower in usage frequency compared to other structures. Accordingly, the most frequently used gerunds and gerundial formations with the highest number of errors were "-(y)IncA" (f=22, \%31,81), "-mAsI için" (f=17, \%29,41), "-DIğI/-DIğIm/-DIğImIz/-DIğInIz/-DIk1ArI zaman" (f=24, \%29,16) and "-mAdAn önce" (f=8, \%25) respectively. Another result of the study showed that the gerunds and gerundial formations that the Arab learners used in written expressions with the fewest number of errors were "-DIkçA" ( $f=9, \% 100)$, "-Ar ...-mAz" (f=3, \%100), "-DIğI hâlde" ( $\mathrm{f}=2, \% 100)$, "-mAksIzIn" ( $\mathrm{f}=2, \% 100)$, "-mAmIz için" ( $\mathrm{f}=2$, \%100), “...-A ...-A” (f=1, \%100), "-DIğI ölçüde” (f=1, \%100), “-DIğIm müddetçe” (f=1, \%100), "-DIğIndAn" (f=1, \%100), "-DIğIndAn beri” (f=1,\%100), "-mAktAn dolayı" (f=1,\%100), and "-mAktAnsA" (f=1, \%100). There is, in fact, a notable matter that cannot be overlooked. These structures were generally restricted a limited number of uses. When viewed from this aspect, the gerunds and gerundial formations that the learners used the most commonly with the fewest number of error were "-DIkçA" (f=9, \%100), “-(y)Ip" (f=46, \%95,66), "-mAk için" (f=196, \%93,88), "-ken" (f=66, \%92,43), "-(y)ArAk" (f=98, \%90,82), "-DIğImda/-DIğIndA/ -DIğImIzdA/ -DIğInIzdA" (f=27, \%88,89), “-DIğI/ -DIğImIz/-DIklArI için” (f=25, \%84), “-mAdAn” (f=12, \%83,34), “-DIktAn sonra” (f=23, \%82,61) and "-DIğI/-DIğIm/ -DIğImIz/ -DIk1ArI gibi” ( $\mathrm{f}=11, \% 81,82)$ respectively.

The findings revealed that further comprehensive studies were necessary for teaching Turkish as a foreign language. Studies employing contrastive analytic approach and error analysis are needed to communicate the findings in detail and explain the causes of the differences. Besides, experimental and quasi-experimental studies involving both learners speaking languages from different language families and coming from different cultural backgrounds and learners speaking languages from the same language family and coming from the same cultural backgrounds should be carried out to resolve the issues of erroneous uses. Such research findings can aid the teaching of Turkish as an international language and the language of science and material development. Accordingly, we proposed that the results of the current research contributed to the curriculum and course materials prepared for Arabicspeaking learners and future research on the concerning topic.

\section{Ethics Committee Approval}

The author(s) confirm(s) that ethical approval was obtained from Bolu Abant İzzet Baysal University (Approval Date: April 15, 2020). 


\section{References}

Adalı, O. (2004). Türkiye Türkçesinde biçimbirimler. İstanbul: Papatya Yayıncılık.

Aksan, D. (1998). Anlambilim. Ankara: Engin Yayınevi.

Albayrak, F. (2010). Türkçe öğrenen Moğol öğrencilerin yazılı anlatım yanlışlarının dil bilgisi açısından değerlendirilmesi (Unpublished master's thesis). Atatürk Üniversitesi Sosyal Bilimler Enstitüsü, Erzurum.

Alshirah, M. (2013). Arap kökenli ögrrencilerin yabancı dil olarak Türkçe ögretiminde karşılaştıkları zorluklar ve çözüm önerileri (Unpublished master's thesis). İstanbul Üniversitesi Sosyal Bilimler Enstitüsü, İstanbul.

Atabay, N., Kutluk, İ., \& Özel, S. (1983). Sözcük türleri. Doğan Aksan (Ed.). Ankara: Türk Dil Kurumu Yayınları.

Avc1, İ. A., Tepeli, Y., \& Caner, M. (2017). B2 düzeyinde yabancı dil olarak Türkçe öğrenenlerin ortaç kullanımları: Bir durum çalışması. Dil Eğitimi ve Araştırmaları Dergisi, 3(1), 19-39.

Bakır, S. (2015). Yabancı uyruklu öğrencilerin öğrenme yaklaşımlarının, yazma becerisi öz yeterliklerinin ve Türkçe yazma becerilerinin incelenmesi (Unpublished doctoral dissertation). Atatürk Üniversitesi Eğitim Bilimleri Enstitüsü, Erzurum.

Banguoğlu, T. (2007). Türkçenin grameri (8th ed.) Ankara: Türk Dil Kurumu Yayınları.

Bayraktar, N. (2018). Türkçede fiilimsiler (2nd ed.) Ankara: Türk Dil Kurumu Yayınları.

Benhür, M. H. T. (1993). Türkiye Türkçesinde sıfat-fiil ve zarf-fiil eklerinin fonksiyonları (Unpublished master's thesis). Gazi Üniversitesi Sosyal Bilimler Enstitüsü, Ankara.

Bilgin, N. (2014). Sosyal bilimlerde içerik analizi teknikler ve örnek çalışmalar (3rd ed.). Ankara: Siyasal Kitabevi.

Boylu, E., Güney, E. Z., \& Özyalçın, K. E. (2017). Yanlış çözümleme yaklaşımına göre Türkçeyi yabancı dil olarak öğrenen B1 seviyesi öğrencilerinin yazılı anlatımlarının değerlendirilmesi. International Journal of Languages' Education and Teaching, 5(3), 184-202.

Bozkurt, F. (2017). Türkiye Türkçesi (dilbilgisi-anlatım) (5th ed.) Konya: Eğitim Yayınevi.

Büyükikiz, K. K. \& Hasırcı, S. (2013). Yabancı dil olarak Türkçe öğrenen öğrencilerin yazılı anlatımlarının yanlış çözümleme yaklaşımına göre değerlendirilmesi. Ana Dili Eğitimi Dergisi, l(4), 51-62.

Büyüköztürk, Ş., Çakmak, E. K., Akgün, Ö. E., Karadeniz, Ş., \& Demirel, F. (2016). Bilimsel araştırma yöntemleri. (22nd ed.). Ankara: Pegem Akademi.

CEFR. (2018). Retrieved on May 13, 2019 from: https://rm.coe.int/cefr-companion-volume-with-newdescriptors-2018/1680787989

CEFR (2013). Retrieved on May 13, 2019 from: https://www.telc.net/fileadmin/user_upload/Publikationen/Diller_iain_Avrupa_Ortak_oneriler_AE eraevesi.pdf

Çetintaş Yıldırım, F. (2010). Türkçede belirteç tümcecikleri: sözbilimsel yapı çözümlemesi çerçevesinde bir siniflandırma önerisi (Unpublished doctoral dissertation). Ankara Üniversitesi Sosyal Bilimler Enstitüsü, Ankara.

Çotuksöken,Y. (2011). Türkiye Türkçesi’nin ekleri. İstanbul: Papatya Yayıncılık. 
Demir, T. (2004). Türkçe dilbilgisi. Ankara: Kurmay Basımevi.

Deniz, G. K. (2017). Yabancı dil olarak Türkçenin öğretiminde fiilimsilerin incelenmesi (Unpublished master's thesis). Çanakkale Onsekiz Mart Üniversitesi Eğitim Bilimleri Enstitüsü, Çanakkale.

Deniz Yılmaz, Ö. (2009). Türkiye Türkçesinde eylemsi. Ankara: Türk Dil Kurumu Yayınları.

Dolunay, S. K. (2012). Türkiye Türkçesinde zaman. Ankara: Berikan Yayınevi.

Ediskun, H. (1999). Türk dilbilgisi (6th ed.). İstanbul: Remzi Kitabevi.

Emiroğlu, S. (2013). Türkçe öğrenen yabancı öğrencilerin yazılı anlatımlarında Türkçenin dil bilgisi ve yazım özellikleriyle ilgili karşılaştı̆̆ zorluklar. Uluslararası Dil ve Edebiyat Çalışmaları Konferansı "Balkanlarda Türkçe” Hëna e Plotë "Beder" Üniversitesi Bildiri Kitabı (pp. 350-369). Tiran/Albenia.

Esawi, H. (2015). Cl düzeyindeki Türkçe ögrenirlerinin yazılı anlatımları üzerine bir hata analizi (Unpublished master's thesis). Yıldırım Beyazıt Üniversitesi Sosyal Bilimler Enstitüsü, Ankara.

Ergin, M. (2004). Türk dil bilgisi. İstanbul: Bayrak Basım/Yayım/Tanıtım.

Gencan, T. N. (2001). Dilbilgisi. Ankara: Ayraç Yayınevi.

Guzev, V. G. \& Yılmaz, Ö. D. (2015). Ulaç (fiilin zarfsı şekli) kavramı üzerine. Dil Araştırmaları, 17, 19-29.

Gülsevin, G. (2001). Türkiye Türkçesinde birleşik zarf-fiiller. Afyon Kocatepe Üniversitesi Sosyal Bilimler Dergisi, 2(2), 125-143.

Güven, E. (2019). Türkçenin belirteç tümceciklerinin yabancı dil olarak ögretimi (Unpublished doctoral dissertation). Hacettepe Üniversitesi Türkiyat Araştırmaları Enstitüsü, Ankara.

Hasırcı, S. (2018). Yabancılara Türkçe öğretenlerin son çekim edatlarının öğretimine ilişkin görüşleri. Uludă̆ Üniversitesi Ĕgitim Fakültesi Dergisi, 31 (Special isssue), 179-203.

Hepçilingirler, F. (2018). Türkçe dilbilgisi- ögretme kitabı. İstanbul: Kırmızı Kedi Yayınevi.

Hengirmen, M. (1995). Türkçe dilbilgisi. Ankara: Engin Yayınevi.

İlker, A. (2019). Kazak dil bilimi öğrencilerinin “-p”, “-arak” ve “-a” zarf-fiil eki üzerinden Türkiye Türkçesine intibak süreçleri. Türk Dünyası, 47, 137-148.

İnan, K. (2013). Yabancı dil olarak Türkçe ögrenen Iranlıların yazılı anlatımları üzerine bir inceleme (Unpublished master's thesis). Gazi Üniversitesi Eğitim Bilimleri Enstitüsü, Ankara.

İnan, K. (2014). Yabancı dil olarak Türkçe öğrenen İranlıların yazılı anlatımlarının hata analizi bağlamında değerlendirilmesi. Turkish Studies, 9(9), 619-649.

Jarbold, N. (2012). Moğalistan’ın Bayan-Ölgii bölgesindeki Kazak ögrencilerin Türkiye Türkçesi ögrenirken yaptıkları yazll anlatım yanlışlarının dil bilgisi açısından incelenmesi (Unpublished master's thesis). Atatürk Üniversitesi Eğitim Bilimleri Enstitüsü, Erzurum.

Kara, M. (2010). Gazi üniversitesi TÖMER öğrencilerinin Türkçe öğrenirken karşılaştıkları sorunlar ve bunların çözümüne yönelik öneriler. Türk Ĕ̆itim Bilimleri Dergisi, 8(3), 661-696.

Karaağaç, G. (2016). Türkçenin dil bilgisi (3rd ed.). Ankara: Akçağ Yayınları.

Karahan, L. (1995). Türkçede söz dizimi. Ankara: Akçă̆ Yayınları. 
Karasar, N. (2012). Bilimsel araştırma yöntemi (24th ed.). Ankara: Nobel Akademik Yayınc1lık.

Kasapoğlu, A. (2012). Yabancı dil olarak Türkçe öğrenenler için ulaçların (zarf-fiillerin) öğretimine yönelik materyal geliştirme (Unpublished master's thesis). Dokuz Eylül Üniversitesi Eğitim Bilimleri Enstitüsü, İzmir.

Kılıç, T. (2017). Yedi iklim Türkçe ve Istanbul yabancılar için Türkçe ögretim setlerindeki fiilimsilerin kullanım sıklığının belirlenmesi (Unpublished master's thesis). Nevşehir Hacı Bektaş Veli Üniversitesi Sosyal Bilimler Enstitüsü, Nevşehir.

Kıvırcık, Ş. Y. (2004). Türkçedeki bazı bileşik yapıların (isim-fiil, sıfat-fiil, zarf-fiil) yabancı dil olarak ögretiminde karşılaşılan sorunlar ve çözüm önerileri (Unpublished master's thesis). Dokuz Eylül Üniversitesi Eğitim Bilimleri Enstitüsü, İzmir.

Koç, N. (1996). Yeni dilbilgisi (3rd ed.). İstanbul: İnkılap Kitabevi.

Korkmaz, Z. (2007). Gramer terimleri sözlüğ̈̈ (3rd ed.). Ankara: Türk Dil Kurumu Yayınları.

Korkmaz, Z. (2009). Türkiye Türkçesi grameri: (Şekil bilgisi) (3rd ed.). Ankara: Türk Dil Kurumu Yayınları.

Koşucu, F. Z. (2007). Türkçenin yabancılara öğretiminde ulaçların düzeylere göre incelenmesi. (Unpublished master's thesis). İstanbul Üniversitesi Sosyal Bilimler Enstitüsü, İstanbul.

Larsen-Freeman, D. (2001). Teaching grammar. In M. Celce-Murcia (Ed.), Teaching English as a second or foreign language (pp. 249-251). USA: Heinle and Heinle.

Polat, H. (2014). Türkçe öğrenen Rusların yazllı anlatımlarında yaptıkları dil yanlışları üzerine bir araştırma. (Unpublished doctoral dissertation). İnönü Üniversitesi Eğitim Bilimleri Enstitüsü, Malatya.

Polat, H. (2018). Türkçedeki bazı ulaçların anadili Rusça, Arapça ve İngilizce olanlara öğretimi “-(y)ı, -mayıp/, -madan” ulaçları. Avrasya Dil Eğitimi ve Araştırmaları Dergisi, 2(1), 90-114.

Şen, E., Köleci, E. O. \& Tülü, T. (2015). Yabancı dil olarak Türkçe sınıflarında ulaçların öğretimine ilişkin öneriler: -(y)arak, -(y)ıp, -dıktan sonra. Turkophone, 2(1), 1-9.

Sezer, A. (1991). Türkçe sözdizimi. Dilbilim ve Türkçe. Ankara: Dil Derneği Yayınları.

Turhan, I. (2005). Çince ve Türkçe'nin söz dizimsel açıdan karşılaştırılması "Çince öğrenen Türk ögrencilerin ve Türkçe ögrenen Çinli ögrrencilerin yazılı anlatım kağıtlarındaki söz dizim hatalarının yanlış çözümleme yöntemiyle saptanması ve değerlendirilmesi” (Unpublished master's thesis). Ankara Üniversitesi Sosyal Bilimler Enstitüsü, Ankara.

TÜİK. (2019). Retrieved on May 13, 2019 from: http://www.tuik.gov.tr/PreTablo.do?alt_id=1067

Uçar, H. (2019). Türkçe-Arapça dilbilgisi öğretiminde transferin problemlerin çözümündeki kolaylaştırıcı etkisi. Mütefekkir Dergisi, 6(11), 145-162.

Ünal, R. (2010). Çağdaş Türkiye Türkçesi’nde başlıca zaman ulaçları. İstanbul: Dilmer Yayınları.

Yağmur Şahin, E. (2013). Yabancı dil olarak Türkçe öğrenen öğrencilerin yazılı anlatımlarındaki ek yanlışları. Tarih Okulu Dergisi, 6(15), 433-449.

Yıldırım, A. \& Şimşek, H. (2016). Sosyal bilimlerde nitel araştırma yöntemleri (10th ed.). Ankara: Seçkin Yayıncılık. 


\section{Türkçe öğrenen C1 düzeyindeki Arap öğrencilerin yazılı anlatım}

\section{çalışmalarındaki ulaçların ve ulaç görevli yapıların görünümleri}

\section{$\ddot{O} \mathbf{z}$}

Ulaç ve ulaç görevli yapılar, Türkçeye büyük bir sadelik ve işlevsellik kazandırıp Türkçenin anlatım gücünü artırırken anlatımın da daha öz ve kıvrak hâle getirilmesine yardımcı olmaktadır. Türkçenin yabancı dil olarak öğretiminde de rehber kabul edilen Diller İçin Avrupa Ortak Öneriler Çerçevesi'nde ulaç ve ulaç görevli yapıların doğru ve etkili kullanımı, dil bilgisel yeterliğin bir parçası olarak $\mathrm{C} 1$ düzeyindeki öğrencilerde bulunması gereken yeterliklerden kabul edilmektedir. Ancak alanyazında, $\mathrm{C} 1$ düzeyindeki öğrencilerin bu konudaki başarımını ortaya koyan çok az sayıda çalışma mevcuttur. Alanyazındaki bu boşluktan yola çıkılarak araştırmanın amacı, Türkçeyi yabancı dil olarak öğrenen $\mathrm{C} 1$ düzeyindeki Arap öğrencilerin yazılı anlatım çalışmalarında kullandıkları ulaç ve ulaç görevli yapıları tespit etmek olarak belirlenmiştir. $\mathrm{Bu}$ amaç doğrultusunda araştırma, nitel durum çalışmasıyla desenlenmiştir. Araştırmanın çalışma grubu, 2019-2020 akademik yılında Karadeniz Bölgesi, İç Anadolu Bölgesi ve Marmara Bölgesi'ndeki üç TÖMER'de öğrenim gören ve araştırmaya gönüllü olarak katılan C1 düzeyindeki 150 Arap öğrencidir. Araştırma verileri, öğrencilerin kur sonu sınavlarındaki yazılı anlatım çalışmalarından belgesel tarama yöntemiyle toplanmıştır. Araştırmanın kapsamına yalnızca ulaçlar ve ulaç görevli yapılar dâhil edilmiştir. Araştırma verilerinin çözümlenmesinde içerik analizinin alt tekniklerinden olan frekans analizi kullanılmıştır. Araştırmada veri toplanan 150 öğrencinin, 32 farklı ulacı ve ulaç görevli yapıyı yazılı anlatım çalışmalarında kullandığı tespit edilmiş̧ir.

Anahtar sözcükler: ulaç; ulaç görevli yapılar; Türkçenin yabancı dil olarak öğretimi; dil bilgisi öğretimi; Arap öğrenciler

\section{AUTHOR BIODATA}

Asst. Prof. Salih Kürşad Dolunay works at Bolu Abant İzzet Baysal University in Faculty of Education Department of Turkish Language and Social Science Education. He has got a PhD in Turkish Language Teaching from Gazi University. Grammar teaching and teaching Turkish as a foreign language are among his fields of interest.

Inst. Hüseyin Karabuğa works at Bolu Abant İzzet Baysal University in Turkish Language Teaching Application \& Research Center. He received his MA from Bolu Abant İzzet Baysal University. Teaching Turkish as a foreign language, writing and speaking skills are among his fields of interest. 